\title{
Reference genes for QRT-PCR tested under various stress conditions in Folsomia candida and Orchesella cincta (Insecta, Collembola)
}

\author{
Muriel E de Boer*†1, Tjalf E de Boer ${ }^{\dagger 1}$, Janine Mariën ${ }^{1}$, \\ Martijn JTN Timmermans ${ }^{1,2}$, Benjamin Nota ${ }^{1}$, Nico M van Straalen ${ }^{1}$, \\ Jacintha Ellers ${ }^{1}$ and Dick Roelofs ${ }^{1}$
}

\begin{abstract}
Address: ${ }^{1}$ Institute of Ecological Science, VU University Amsterdam, De Boelelaan 1085, $1081 \mathrm{HV}$, Amsterdam, The Netherlands and ${ }^{2}$ Current address: Faculty of Natural Sciences, Department of Ecology \& Evolution, Imperial College London Exhibition Road, London SW7 2AZ, UK

Email: Muriel E de Boer* - muriel.de.boer@falw.vu.nl; Tjalf E de Boer - tjalf.de.boer@falw.vu.nl; Janine Mariën - janine.marien@falw.vu.nl; Martijn JTN Timmermans - m.timmermans@nhm.ac.uk; Benjamin Nota - ben.nota@falw.vu.nl; Nico M van

Straalen - nico.van.straalen@falw.vu.nl; Jacintha Ellers - jacintha.ellers@falw.vu.nl; Dick Roelofs - dick.roelofs@falw.vu.nl

* Corresponding author †Equal contributors
\end{abstract}

Published: I June 2009

BMC Molecular Biology 2009, 10:54 doi:10.1 186/147/-2199-10-54

This article is available from: http://www.biomedcentral.com/I47I-2/99//0/54

(c) 2009 de Boer et al; licensee BioMed Central Ltd.

This is an Open Access article distributed under the terms of the Creative Commons Attribution License (http://creativecommons.org/licenses/by/2.0), which permits unrestricted use, distribution, and reproduction in any medium, provided the original work is properly cited.
Received: 14 November 2008

Accepted: I June 2009

\begin{abstract}
Background: Genomic studies measuring transcriptional responses to changing environments and stress currently make their way into the field of evolutionary ecology and ecotoxicology. To investigate a small to medium number of genes or to confirm large scale microarray studies, Quantitative Reverse Transcriptase PCR (QRT-PCR) can achieve high accuracy of quantification when key standards, such as normalization, are carefully set. In this study, we validated potential reference genes for their use as endogenous controls under different chemical and physical stresses in two species of soil-living Collembola, Folsomia candida and Orchesella cincta. Treatments for $F$. candida were cadmium exposure, phenanthrene exposure, desiccation, heat shock and $\mathrm{pH}$ stress, and for $O$. cincta cadmium, desiccation, heat shock and starvation.
\end{abstract}

Results: Eight potential reference genes for $F$. candida and seven for $O$. cincta were ranked by their stability per stress factor using the programs geNorm and Normfinder. For $F$. candida the succinate dehydrogenase (SDHA) and eukaryotic transcription initiation factor IA (ETIF) genes were found the most stable over the different treatments, while for 0 . cincta, the beta actin $(A C T b)$ and tyrosine 3-monooxygenase (YWHAZ) genes were the most stable.

Conclusion: We present a panel of reference genes for two emerging ecological genomic model species tested under a variety of treatments. Within each species, different treatments resulted in differences in the top stable reference genes. Moreover, the two species differed in suitable reference genes even when exposed to similar stresses. This might be attributed to dissimilarity of physiology. It is vital to rigorously test a panel of reference genes for each species and treatment, in advance of relative quantification of QRT-PCR gene expression measurements. 


\section{Background}

Genomic techniques have undergone major developments in the last two decades. As a result, they have become conducive for evolutionary and ecotoxicological studies, which generally use non genomic-model organisms. Quantitative Reverse-Transcriptase Polymerase Chain Reaction (QRT-PCR) is a technique to estimate gene expression levels. This technique is often used to confirm high throughput systems like microarrays. Its application has mainly been limited to small numbers of genes per experiment due to constraints of low throughput coinciding with relatively high costs per assay. This is about to change, as high throughput QRT-PCR systems using small volume (capillary) PCR are becoming available [1]. QRT-PCR is a valuable tool for ecological studies as it provides a relatively straightforward way to measure the direct transcriptional response of an organism exposed to different treatments [2]. QRT-PCR has been applied to study adaptive evolution at the transcriptional level [3-6]. For instance, Roelofs et al. [7] conducted a QRT-PCR study to assess the relevance of transcriptional regulation in the adaptive evolution of stress tolerance.

The conditions that have to be met for a successful QRTPCR experiment are reviewed by Bustin [8]. Different strategies have been developed for quantifying gene expression with QRT-PCR data. The most widely used method is to quantify the relative amount of target mRNA between samples, using for instance the comparative CT (2- $\Delta \Delta \mathrm{CT})$ method [9], or the more comprehensive Pfaffl method where relative quantities are adjusted for amplification efficiencies. Relative quantification methods depend on reference genes for normalization [10]. QRTPCR reference genes, sometimes called 'housekeeping' genes, can either be internal, when measured in the same reaction tube as the target gene, or external, when measured in a different reaction tube. The use of reference genes is necessary to correct for factors such as RNA input differences and reverse transcriptase efficiency variation [11].

An essential requirement for QRT-PCR reference genes is stability of their transcriptional level across the various conditions to which an organism is exposed during an experiment. Classically, the most used reference genes are carry-overs from the Northern-blot days [12] such as beta actin $(A C T b)$, glyceraldehyde-3P-dehydrogenase $(G A P D H)$ and ribosomal RNA genes $(18 S, 28 S)$. Unfortunately, these classical reference genes are not always found to be suitable for this use. For example, mRNA levels of $A C T b$ and GAPDH can fluctuate widely in human T-cells exposed to different treatments [13]. Also, commonly used housekeeping genes like ACTb, GAPDH, cyclophilin A $(C Y P)$ and $28 S$ are up or down regulated in cell lines exposed to hypoxia stress [14]. Therefore, it is vital to val- idate the stability of a panel of reference genes in order to select the most suitable ones for each new treatment and species of choice.

Currently two Visual Basic Applications for Microsoft Excel are widely used to determine reference gene suitability: geNorm [15] and Normfinder [16]. GeNorm is based on the principle that the expression ratio of two ideal control genes should be identical in all samples and experimental conditions. It calculates gene expression stability (M), which is the mean pair-wise variation between an individual gene and all other tested reference genes. Subsequently, the least stable reference gene (highest $M$ value) is excluded from the set and the calculation is reiterated until the two most stable reference genes remain. Normfinder [16] estimates intergroup and intragroup variation to calculate reference gene stability and to rank them. As with geNorm it calculates a stability value for each potential reference gene but it uses a variance model based approach (mixed linear effect modeling), instead of the reiterative approach used by geNorm. Normfinder calculates intragroup variability for the genes in each of the groups, and the intergroup variability or bias among the groups [17]. Since the program can differentiate between groups, Normfinder is best suited when the stability of reference genes needs to be assessed over multiple treatments. When reference gene stability only needs to be calculated for samples exposed to a single treatment the two methods are similar and should give the same results [16].

In this paper we develop a panel of reference genes for two species of springtails (Collembola), and study their stability across various treatments. Collembola are important model organisms in evolutionary ecology and ecotoxicological studies. The soil-dwelling collembolan Folsomia candida is a standard test animal used in a soil pollution test that is certified by the International Organization for Standardization [18]. Its parthenogenetic mode of reproduction and the availability of a recently sequenced Expressed Sequence Tag (EST) database, make F. candida also a proper test animal for genomic studies on the effects of soil pollution [19-21]. An F. candida microarray is currently in use for testing soil toxicants [22] and physical conditions (Timmermans et al., unpubl. data; De Boer et al., unpubl. data). Therefore, confirmation of microarray results by QRT-PCR is abound. Orchesella cincta is a sexually reproducing collembolan that lives in the litter layer rather than in the soil and is generally used to study adaptation and phenotypic plasticity [23,24]. Furthermore, it is an emerging genomic model to study adaptive evolution in polluted environments [20,21,25].

Here we study the stability of potential QRT-PCR reference genes across various treatments. We exposed the two 
collembolan species to several stressors (F. candida: cadmium, phenanthrene, desiccation, temperature and $\mathrm{pH}$ stress. O. cincta: cadmium, desiccation, temperature stress and starvation) that are currently under investigation in gene expression studies. Based on previous studies (e.g. $[12,26])$, a panel of potential QRT-PCR reference genes was developed (Table 1) using the Collembola EST database Collembase http://www.collembase.org[20]. In addition, a target gene (expected to be differential) was measured for each treatment, to validate the impact of the treatment at the transcriptional level of the organism. The stability of the potential reference genes was determined using both geNorm and Normfinder.

\section{Results}

\section{Expression levels under different conditions}

Average cycle threshold (Ct) values varied widely between conditions and treatments, and ranged between 9.7 (28S, O. cincta) and 28.6 (CYP, F. candida, see Additional file 1 for an overview). An example of the different expression levels in treatments and conditions is given in Figure 1 for $A C T b$ and the differential metallothionein gene $(M T)$ of O. cincta.

In $O$. cincta, the target gene $M T$ showed a 7 fold up regulation $(F R)$ in the cadmium treatment $(P<0.05)$ and
HSP70 was 5 fold up regulated after heat shock ( $<<$ 0.001). Starvation and desiccation treatments showed no significant changes in either of the two target genes, implying that those treatments had fairly small effects, at least on the transcriptional response of these two genes. In $F$. candida, all but one treatment showed a significant effect on the target genes (cadmium: mitochondrial chaperone BCS-1 (BCS1), FR = 20, P < 0.0001; phenanthrene: $B C S 1, \mathrm{FR}=6.4, \mathrm{P}=0.001$; temperature: HSP70, FR $>2, \mathrm{P}$ $<0.001$ (for all conditions); desiccation: Cuticle protein $(C P), \mathrm{FR}=4, \mathrm{P}<0.05)$. The $\mathrm{pH}$ treatment showed no significant differences in the target V-type ATPase (ATPase); in fact the ATPase gene used in the $\mathrm{pH}$ treatment was more stable than most reference genes, again implying that this treatment had only a modest effect on the transcriptional level of this gene.

\section{Ranking of the reference genes}

Stability rankings were established using geNorm and Normfinder. As described in the methods section, the Normfinder analysis should be executed with genes that show no substantial treatment-specific response [17]. Therefore, differential genes were excluded in most cases as well as some of the other genes that showed a systematic response to the treatment (see Table 2 for an overview).

Table I: Overview of reference genes and differentially expressed genes in Folsomia candida and Orchesella cincta

\begin{tabular}{|c|c|c|c|c|}
\hline Gene name & Symbol & GenBank Accesion no. & Collembase id & Gene Ontology \\
\hline Beta Actin & ACTb & $\begin{array}{l}\text { FC: } \text { EV473840 } \\
\text { OC: } \underline{A Y 779737}\end{array}$ & $\begin{array}{l}\mathrm{Fcc0} 01756 \\
\mathrm{n} / \mathrm{a}\end{array}$ & $\begin{array}{l}\text { structural constituent of cytoskeleton (F) } \\
\text { GO:0005200 }\end{array}$ \\
\hline $\begin{array}{l}\text { Glyceraldehyde 3-Phosphatase } \\
\text { dehydrogenase }\end{array}$ & GAPDH & $\begin{array}{l}\text { FC: } \text { EV479869 } \\
\text { OC: } \text { FJ009068 }\end{array}$ & $\begin{array}{l}\text { Fcc05545 } \\
\mathrm{n} / \mathrm{a}\end{array}$ & Glycolysis (P) GO:0006096 \\
\hline Ubiquitin conjugating enzyme & $U B C$ & $\begin{array}{l}\text { FC: } E \text { EV475860 } \\
\text { OC: } \mathrm{n} / \mathrm{a}\end{array}$ & $\begin{array}{l}\text { Fcc00615 } \\
\mathrm{n} / \mathrm{a}\end{array}$ & $\begin{array}{l}\text { Ubiquitin-protein ligase activity (F) } \\
\text { GO:0004842 }\end{array}$ \\
\hline Succinate dehydrogenase & SDHA & $\begin{array}{l}\text { FC: EV476739 } \\
\text { OC: } \text { Fj009079 }\end{array}$ & $\begin{array}{l}\text { Fcc06005 } \\
\mathrm{n} / \mathrm{a}\end{array}$ & Tricarboxylic acid cycle (P) GO:0006099 \\
\hline Tyrosine 3-monooxygenase & YWHAZ & $\begin{array}{l}\text { FC: } \frac{\mathrm{EV} 474941}{\mathrm{OC}: \mathrm{n} / \mathrm{a}}\end{array}$ & $\begin{array}{l}\text { Fcc02512 } \\
\text { Occ004I2 }\end{array}$ & $\begin{array}{l}\text { Protein domain specific binding }(\mathrm{F}) \\
\text { GO:0019904 }\end{array}$ \\
\hline Elongation factor I-alpha & EFIa & $\begin{array}{l}\text { FC: } \mathrm{EV} 473706 \\
\text { OC: } \mathrm{AH} 009877\end{array}$ & $\begin{array}{l}\text { Fcc05454 } \\
\mathrm{n} / \mathrm{a}\end{array}$ & Protein biosynthesis (P) GO:00064I2 \\
\hline $\begin{array}{l}\text { Eukaryotic Transcription Initiation } \\
\text { Factor 5a }\end{array}$ & ETIF & $\begin{array}{l}\text { FC: } \mathrm{EV479461} \\
\text { OC: } \mathrm{n} / \mathrm{a}\end{array}$ & $\begin{array}{l}\mathrm{Fcc0} 02111 \\
\mathrm{n} / \mathrm{a}\end{array}$ & Protein biosynthesis (P) GO:00064I2 \\
\hline Cyclophilin A & CYP & $\begin{array}{l}\text { FC: } E \text { EV475615 } \\
\text { OC: } \mathrm{n} / \mathrm{a}\end{array}$ & $\begin{array}{l}\mathrm{Fcc0} 01655 \\
\mathrm{n} / \mathrm{a}\end{array}$ & Protein folding (P) GO:0006457 \\
\hline $28 \mathrm{~S}$ & 285 & $\begin{array}{l}\text { FC: } n / a \\
\text { OC: } A F 483443\end{array}$ & $\begin{array}{l}\mathrm{n} / \mathrm{a} \\
\mathrm{n} / \mathrm{a}\end{array}$ & Large ribosomal subunit (C) G00022625 \\
\hline Alpha Tubulin & $T B a$ & $\begin{array}{l}\text { FC: } n / a \\
\text { OC: GDI80623 }\end{array}$ & $\begin{array}{l}\mathrm{n} / \mathrm{a} \\
\mathrm{n} / \mathrm{a}\end{array}$ & $\begin{array}{l}\text { contributes to the structural integrity of a } \\
\text { cytoskeletal structure }(F) \text { GO:0005200 }\end{array}$ \\
\hline Heat Shock Protein 70 & HSP70 & $\begin{array}{l}\text { FC: } E \text { EV473626 } \\
\text { OC: Fj009069 }\end{array}$ & $\begin{array}{l}\mathrm{Fcc01609} \\
\mathrm{n} / \mathrm{a}\end{array}$ & Response to unfolded protein (P) GO:0006986 \\
\hline V-type ATPase & ATPase & $\begin{array}{l}\text { FC: } \overline{E V 476428} \\
\text { OC: } \mathrm{n} / \mathrm{a}\end{array}$ & $\begin{array}{l}\text { Fcc04630 } \\
\mathrm{n} / \mathrm{a}\end{array}$ & Hydrogen transport activity (F) GO:00I5078 \\
\hline Cuticle Protein & $C P$ & $\begin{array}{l}\text { FC: } E V 479600 \\
\text { OC: } \mathrm{n} / \mathrm{a}\end{array}$ & $\begin{array}{l}\mathrm{Fcc0} 040 \mathrm{I} \\
\mathrm{n} / \mathrm{a}\end{array}$ & $\begin{array}{l}\text { a molecule that contributes to the structural } \\
\text { integrity of a cuticle (F) GO:0042302 }\end{array}$ \\
\hline Mitochondrial chaperone BCSI & BCSI & $\begin{array}{l}\text { FC: } \text { EV473062 } \\
\text { OC: } \mathrm{n} / \mathrm{a}\end{array}$ & $\begin{array}{l}\mathrm{Fcc00I0I} \\
\mathrm{n} / \mathrm{a}\end{array}$ & ATP binding (F) GO:0005524 \\
\hline Metallothionein & MT & $\begin{array}{l}\text { FC: } n / a \\
\text { OC: } \underline{A F 036345}\end{array}$ & $\begin{array}{l}\mathrm{n} / \mathrm{a} \\
\text { Occ00204 }\end{array}$ & Metal ion binding (F) GO:0046872 \\
\hline
\end{tabular}



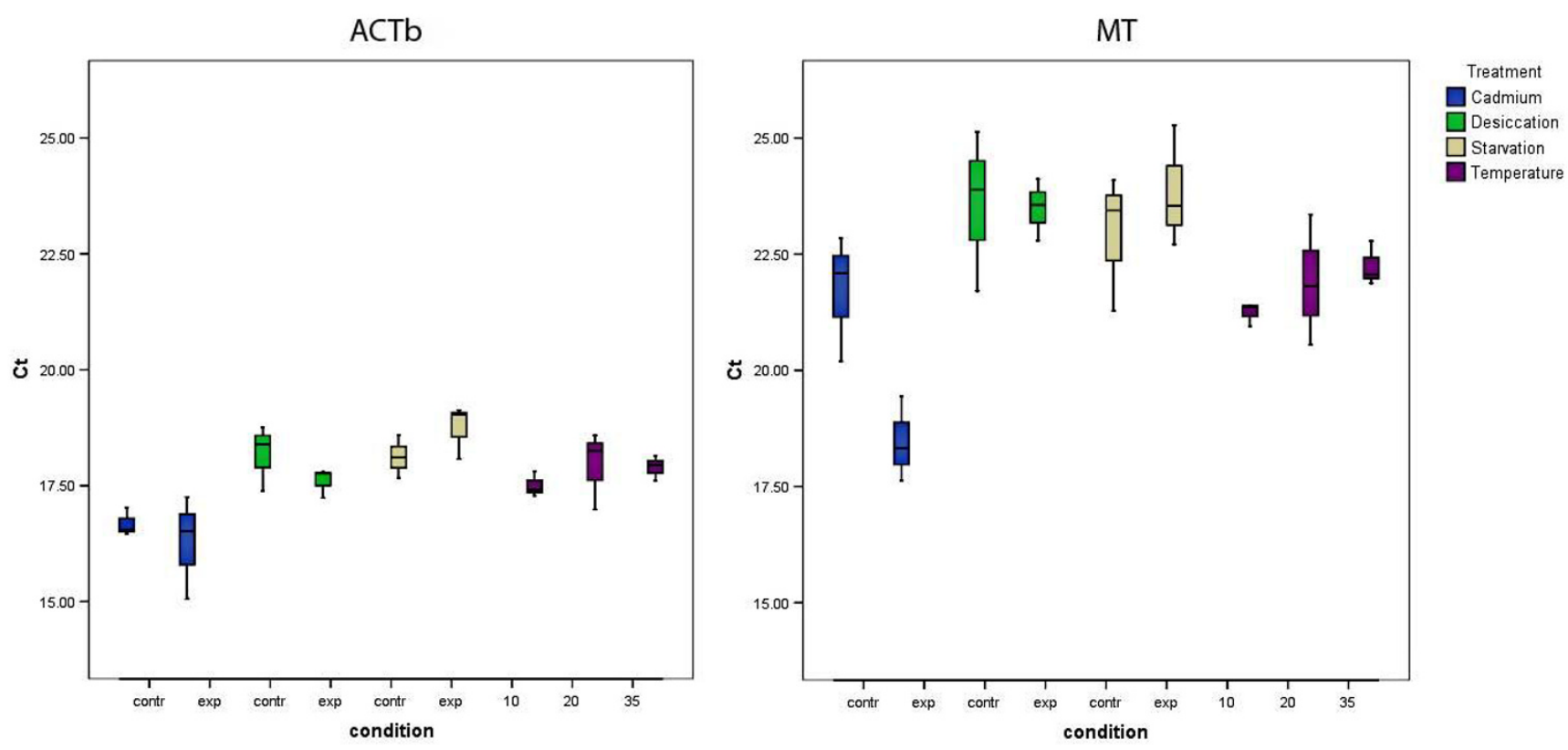

Figure I

Ct values of 2 genes from Orchesella cincta exposed to the different treatments. Average $C_{t}$ values between the biological replicates of the beta actin (ACTb) and metallothionein (MT) genes from Orchesella cincta exposed to the cadmium, desiccation, starvation and temperature treatments. Exp stands for the exposed group, contr for the control group. 0,10 and 35 in the temperature treatment stand for the different temperatures (in ${ }^{\circ} \mathrm{C}$ ) the animals were exposed to.

The stability rankings generated by geNorm or Normfinder were largely similar, even though the ranking order of the genes differed to some extent. An overview of which genes to use for each treatment is found in Table 3. From the three treatments tested for both species, only the cadmium treatment gave similar results between $F$. candida (tyrosine 3-monooxygenase (YWHAZ), succinate dehydrogenase (SDHA) and GAPDH) and O. cincta (alpha-tubulin $(T B a)$ - not tested in F. candida - SDHA and YWHAZ). To compare interspecies parallels, an additional geNorm analysis was done including only the reference genes available for both species (see Additional file 2). This did not change the fact that most rankings did not correspond between species. In F. candida, overall analyses show the same outcomes for the cadmium treatment and the phenanthrene treatment: YWHAZ, SDHA, $G A P D H$. For the temperature and desiccation treatments (F. candida) results also overlapped with SDHA ETIF and elongation factor $1 \alpha(E F 1 a)$ being the best suited reference genes. The results for $O$. cincta seem to be quite variable. The commonly used reference gene $A C T b$ is placed in all top rankings, but not in the cadmium treatment. 28S, a well known but also controversial reference gene to use, showed a high stability in the temperature treatment. Also remarkable is the stability of HSP70, expected to be differential, in the desiccation and starvation treatments. This result has been reported previously for Drosophila mela- nogaster, which did not show an increase in HSP70Aa mRNA levels in response to starvation and desiccation [27]. Despite the fact that the ranking of reference genes shows no typical overall uniformity over all different treatments, the most generally applicable reference genes are suggested to be: $A C T b, Y W H A Z$ and $T B a$ for $O$. cincta and SDHA, ETIF and YWHAZ for F. candida.

\section{Optimum number of reference genes}

The optimum numbers of reference genes are shown in Table 3. In only two out of nine treatments the two methods agreed on the number of genes to use for normalization (two genes in these cases). However, in nearly all cases either geNorm or Normfinder recommended the use of two reference genes. Comparing the two sets proposed by either program, the differences in significance levels and relative expression levels of a differential gene were found to be very small.

\section{Effect of method of normalization on relative expression of HSP70}

We selected the temperature treatment with the differential HSP70 to illustrate the effects of reference gene selection on the calculated relative expression level of a gene of interest. This treatment was chosen because there were four different conditions and HSP70 expression clearly responded differently to each of these conditions. 
Table 2: Omitted and remaining genes and their absolute total biases after preselection for Normfinder analysis

\begin{tabular}{|c|c|c|c|c|c|c|c|c|c|c|c|}
\hline \multicolumn{6}{|c|}{ Folsomia candida } & \multicolumn{6}{|c|}{ Orchesella cincta } \\
\hline Treatment & $\begin{array}{l}\text { Bias } \\
\text { treshold }\end{array}$ & $\begin{array}{l}\text { Omitted } \\
\text { genes }\end{array}$ & Bias & $\begin{array}{l}\text { Remaining } \\
\text { genes }\end{array}$ & Bias & Treatment & $\begin{array}{l}\text { Bias } \\
\text { treshold }\end{array}$ & $\begin{array}{l}\text { Omitted } \\
\text { genes }\end{array}$ & Bias & $\begin{array}{l}\text { Remaining } \\
\text { genes }\end{array}$ & Bias \\
\hline \multirow[t]{7}{*}{ Temperature } & 2.24 & YWHAZ & 3.78 & ETIF & 1.01 & Temperature & 1.08 & MT & 1.38 & $T B a$ & 0.24 \\
\hline & & HSP70 & 4.95 & $U B C$ & 1.05 & & & HSP70 & 3.49 & $S D H A$ & 0.32 \\
\hline & & & & SDHA & 1.19 & & & & & YWHAZ & 0.45 \\
\hline & & & & EFla & 1.38 & & & & & EFIa & 0.51 \\
\hline & & & & CYP & 1.42 & & & & & $28 S$ & 0.58 \\
\hline & & & & GAPDH & 1.74 & & & & & $A C T b$ & 0.71 \\
\hline & & & & $A C T b$ & 2.02 & & & & & GAPDH & 0.87 \\
\hline \multirow[t]{7}{*}{ Desiccation } & 1.72 & GAPDH & 2.19 & $U B C$ & 0.43 & Desiccation & 0.16 & SDHA & 0.26 & HSP7O & 0.02 \\
\hline & & $C P$ & 4.99 & CYP & 0.70 & & & $28 S$ & 0.27 & GAPDH & 0.06 \\
\hline & & & & EFla & 0.70 & & & MT & 0.34 & YWHAZ & 0.07 \\
\hline & & & & ETIF & 0.97 & & & & & EFIa & 0.09 \\
\hline & & & & YWHAZ & 1.13 & & & & & $T B a$ & 0.10 \\
\hline & & & & SDHA & 1.18 & & & & & $A C T b$ & 0.15 \\
\hline & & & & $A C T b$ & 1.54 & & & & & & \\
\hline \multirow[t]{7}{*}{ Cadmium } & 1.44 & ETIF & 1.64 & $A C T b$ & 0.20 & Cadmium & 0.76 & GAPDH & 0.81 & HSP70 & 0.01 \\
\hline & & $B C S I$ & 4.31 & EFla & 0.32 & & & $M T$ & 2.88 & $A C T b$ & 0.03 \\
\hline & & & & CYP & 0.84 & & & & & SDHA & 0.27 \\
\hline & & & & YWHAZ & 0.90 & & & & & $28 S$ & 0.29 \\
\hline & & & & SDHA & 0.95 & & & & & YWHAZ & 0.44 \\
\hline & & & & GAPDH & 1.11 & & & & & $T B a$ & 0.50 \\
\hline & & & & $U B C$ & 1.24 & & & & & EFIa & 0.60 \\
\hline \multirow[t]{7}{*}{ Phenanthrene } & 0.85 & ETIF & 0.89 & UBC & 0.14 & Starvation & 0.33 & MT & 0.35 & $A C T b$ & 0.07 \\
\hline & & BCSI & 3.00 & $A C T b$ & 0.21 & & & EFIa & 0.55 & HSP7O & 0.09 \\
\hline & & & & EFla & 0.33 & & & GAPDH & 0.58 & YWHAZ & 0.13 \\
\hline & & & & YWHAZ & 0.37 & & & SDHA & 0.67 & $T B a$ & 0.14 \\
\hline & & & & SDHA & 0.38 & & & & & $28 S$ & 0.16 \\
\hline & & & & GAPDH & 0.55 & All treatments & 1.21 & total RNA & 2.06 & $A C T b$ & 0.34 \\
\hline & & & & CYP & 0.79 & & & MT & 3.33 & SDHA & 0.53 \\
\hline \multirow[t]{6}{*}{$\mathrm{pH}$} & 0.67 & EFla & 0.67 & ETIF & 0.36 & & & & & $T B a$ & 0.55 \\
\hline & & GAPDH & 0.81 & $U B C$ & 0.38 & & & & & $28 S$ & 0.91 \\
\hline & & YWHAZ & 0.90 & SDHA & 0.49 & & & & & YWHAZ & 1.00 \\
\hline & & CYP & 1.02 & $A C T b$ & 0.57 & & & & & EFIa & 1.04 \\
\hline & & & & ATPase & 0.59 & & & & & GAPDH & 1.05 \\
\hline & & & & & & & & & & HSP70 & 1.20 \\
\hline
\end{tabular}

Pre-selection of genes prior to Normfinder analysis based on a threshold for maximum allowable bias of 0.13 times the standard deviation of the total absolute bias of a treatment. For each treatment, bias thresholds are given as well as the corresponding omitted and remaining genes and their absolute total biases per treatment (total RNA input was only included in the All treatment analysis for Orchesella cincta).

We normalized HSP70 expression in the F. candida temperature treatment with four different sets of reference genes: i) only with a commonly used single reference gene $(A C T b)$; ii) with the appropriate number of selected genes according to the geNorm and iii) the Normfinder analysis and iv) with all available reference genes in the $F$. candida temperature dataset. Each set of reference genes showed significant upregulation of HSP70 expression in the animals exposed to $0^{\circ} \mathrm{C}$ and $30^{\circ} \mathrm{C}$ as compared to those exposed to $10^{\circ} \mathrm{C}$ and $20^{\circ} \mathrm{C}(\mathrm{P}<0.05)$, as well as a significant difference between $10^{\circ} \mathrm{C}$ and $20^{\circ} \mathrm{C}$ (Figure 2). However, the difference in $H S P 70$ expression between $0^{\circ} \mathrm{C}$ and $30^{\circ} \mathrm{C}$ was only significant when using the reference genes proposed by the geNorm and Normfinder analysis. This indicates that selection of reference genes can influence the resolution with which differences in gene expression between two samples can be detected.

\section{Ranking O. cincta reference genes over all treatments}

Making comparisons between experiments is difficult when no standardization of reaction conditions has taken place [28]. Reverse transcription is the most crucial step in the introduction of technical sampling variation in the QRT-PCR procedure [29]. In the O. cincta dataset we attempted to meet the standards needed for a multi-treatment analysis, which allowed us to analyze the whole $O$. cincta dataset similarly to the single treatment analyses using Normfinder. We also included a non-normalized situation ('total RNA input') which was equal for all samples. The differential MT was omitted from ranking due to 
Table 3: Most stable reference genes per treatment calculated by geNorm and Normfinder

\begin{tabular}{|c|c|c|c|c|c|c|c|c|c|}
\hline \multicolumn{5}{|c|}{ Folsomia candida } & \multicolumn{5}{|c|}{ Orchesella cincta } \\
\hline \multirow[t]{2}{*}{ Treatment } & \multicolumn{2}{|c|}{$\begin{array}{l}\text { Top } 3 \text { most stable } \\
\text { genes }\end{array}$} & \multicolumn{2}{|c|}{ Optimum no. genes } & \multirow[t]{2}{*}{ Treatment } & \multicolumn{2}{|c|}{$\begin{array}{l}\text { Top } 3 \text { most stable } \\
\text { genes }\end{array}$} & \multicolumn{2}{|c|}{ Optimum no. genes } \\
\hline & Normfinder & GeNorm & $\begin{array}{l}\text { Norm } \\
\text { finder }\end{array}$ & GeNorm & & $\begin{array}{l}\text { Norm } \\
\text { finder }\end{array}$ & GeNorm & Normfinder & GeNorm \\
\hline \multirow[t]{3}{*}{ Temperature } & SDHA & $S D H A$ & 2 & $>3$ & Temperature & $28 s$ & YWHAZ & $>3$ & 2 \\
\hline & ETIF & ETIF & & & & $A C T b$ & $A C T b$ & & \\
\hline & EFIa & EFIa & & & & YWHAZ & $28 s$ & & \\
\hline \multirow[t]{3}{*}{ Desiccation } & SDHA & $S D H A$ & 2 & 3 & Desiccation & $A C T b$ & $A C T b$ & 2 & 2 \\
\hline & ETIF & ETIF & & & & GAPDH & GAPDH & & \\
\hline & EFIa & GAPDH & & & & EFIa & EFIa & & \\
\hline \multirow[t]{3}{*}{ Cadmium } & YWHAZ & YWHAZ & 3 & 2 & Cadmium & $T B a$ & $T B a$ & $>3$ & 2 \\
\hline & $S D H A$ & SDHA & & & & $S D H A$ & YWHAZ & & \\
\hline & GAPDH & GAPDH & & & & YWHAZ & $S D H A$ & & \\
\hline \multirow[t]{3}{*}{ Phenanthrene } & $S D H A$ & $S D H A$ & 2 & 2 & Phenanthrene & $\mathrm{n} / \mathrm{a}$ & $\mathrm{n} / \mathrm{a}$ & $\mathrm{n} / \mathrm{a}$ & $\mathrm{n} / \mathrm{a}$ \\
\hline & YWHAZ & YWHAZ & & & & $\mathrm{n} / \mathrm{a}$ & $\mathrm{n} / \mathrm{a}$ & & \\
\hline & GAPDH & GAPDH & & & & $\mathrm{n} / \mathrm{a}$ & $\mathrm{n} / \mathrm{a}$ & & \\
\hline \multirow[t]{3}{*}{$\mathrm{pH}$} & $U B C$ & $A C T b$ & $>3$ & $>3$ & $\mathrm{pH}$ & $\mathrm{n} / \mathrm{a}$ & $\mathrm{n} / \mathrm{a}$ & $\mathrm{n} / \mathrm{a}$ & $\mathrm{n} / \mathrm{a}$ \\
\hline & ETIF & CYP & & & & $\mathrm{n} / \mathrm{a}$ & $\mathrm{n} / \mathrm{a}$ & & \\
\hline & ACTb & EFIa & & & & $\mathrm{n} / \mathrm{a}$ & $\mathrm{n} / \mathrm{a}$ & & \\
\hline \multirow[t]{3}{*}{ Starvation } & $\mathrm{n} / \mathrm{a}$ & $\mathrm{n} / \mathrm{a}$ & $\mathrm{n} / \mathrm{a}$ & $\mathrm{n} / \mathrm{a}$ & Starvation & $A C T b$ & TBA & $>3$ & 2 \\
\hline & $\mathrm{n} / \mathrm{a}$ & $\mathrm{n} / \mathrm{a}$ & & & & YWHAZ & YWHAZ & & \\
\hline & $\mathrm{n} / \mathrm{a}$ & $\mathrm{n} / \mathrm{a}$ & & & & $T B a$ & $S D H A$ & & \\
\hline \multirow{3}{*}{ All treatments } & $\mathrm{n} / \mathrm{a}$ & $\mathrm{n} / \mathrm{a}$ & $\mathrm{n} / \mathrm{a}$ & $\mathrm{n} / \mathrm{a}$ & All treatments & $A C T b$ & $\mathrm{n} / \mathrm{a}$ & $\mathrm{n} / \mathrm{a}$ & $\mathrm{n} / \mathrm{a}$ \\
\hline & $\mathrm{n} / \mathrm{a}$ & $\mathrm{n} / \mathrm{a}$ & & & & $T B a$ & $\mathrm{n} / \mathrm{a}$ & & \\
\hline & $\mathrm{n} / \mathrm{a}$ & $\mathrm{n} / \mathrm{a}$ & & & & YWHAZ & $\mathrm{n} / \mathrm{a}$ & & \\
\hline
\end{tabular}

bias beyond the bias threshold as well as 'total RNA input' (Table 2, see materials section and Additional file 3. Although geNorm is less suited to handle heterogeneity than Normfinder, both algorithms produced the same top three of generally applicable reference genes: $A C T b T B a$, and YWHAZ.

\section{Discussion and Conclusion}

In this study we identified appropriate reference genes of two collembolan species that show invariant expression across experimental treatments. The most important result of our study is the lack of similarity in stability of genes i) within the species upon exposure to different treatments, and ii) between species that have undergone similar treatments. The two collembolan species have a distinct physiology and ecology, but they belong to phylogenetically related families [30]. An earlier study on two flatfish species with a comparable phylogenetic relatedness as the two collembolan species used here, found congruent results in reference gene stabilities between the two species [31]. In our study, differences were most pronounced in the temperature and desiccation treatments, while the cadmium treatments show a greater congruency between species. It may be argued that the physiological response to xenobiotic stress is more similar in the two species than responses to the environmental factors. Still, experimental methods also differed between species and therefore it cannot be excluded that part of the observed interspecific differences was due to differences in experimental set-up.

Previously, it has been suggested that the results of reference gene selection studies might serve as a resource for future gene expression studies in the same or related species $[31,32]$. Indeed, some genes were stable across different treatments. ACTb and YWHAZ were the dominant genes found in the top of the rankings of three out of four $O$. cincta treatments, but this general pattern did not hold up for $A C T b$ in the cadmium treatment and YWHAZ in the desiccation treatment. In $F$. candida, the two chemical treatments (cadmium and phenanthrene) and the environmental treatments (temperature, desiccation and $\mathrm{pH}$ stress) differed in selected reference genes, indicating that different classes of physiological responses, for instance detoxification and acclimation, can be expected to cause fluctuations in different 'housekeeping' genes to maintain cellular homeostasis. Therefore one cannot assume that two species responding similarly to a certain treatment will also respond in a similar way to another treatment. In addition, differences in priming strategy and QRT-PCR assay characteristics can also introduce variation in stability comparisons. In the light of our present results we 


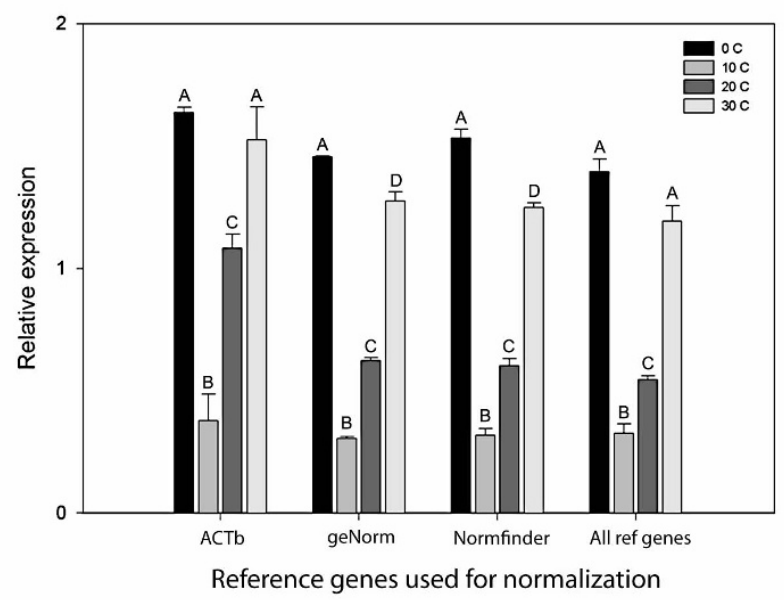

Figure 2

HSP70 expression of Folsomia candida in the temperature treatment normalized with four different sets of reference genes. HSP70 expression between different pools of $F$. candida exposed to different temperatures, normalized with four different sets of reference genes (ACTb: only beta-actin; the best set selected by geNorm (SDHA \&ETIF); the best set selected by Normfinder (ETIF, SDHA, EFI $a \& U B C$ ) and all available reference genes). One-way ANOVA analysis with Bonferroni post-hoc test revealed significant differences $(P<0.05)$ between 0,10 and $20^{\circ} \mathrm{C}$ and between 10,20 and $30^{\circ} \mathrm{C}$ in all normalization sets. Significant differences between 0 and $30^{\circ} \mathrm{C}$ were only detected when normalized with the optimum sets of reference genes selected by either geNorm or Normfinder. The letters above the bars indicate significant differences where different letters between bars represent a significant difference within I normalization set.

must caution against the use of literature data from related species to select a normalization standard, unless careful notion is taken of the parallels and differences in the technical context of the experiment as well as the internal processes of the organisms that are being studied.

Optimizing a set of reference genes not only requires making the right choice of genes, it also implies choosing the right number of genes. The difference in calculated levels of HSP70 expression, using different sets of reference genes, exemplifies the importance of the number of reference genes used. Resolution was too low to detect small differences in expression, when either a single reference gene was used for normalization or when all available reference genes were included. In fact the small difference between $0^{\circ} \mathrm{C}$ and $30^{\circ} \mathrm{C}$ was only statistically significant when normalization was done with the sets proposed by geNorm and Normfinder.

In the geNorm analysis, inclusion of a differential gene gives insight into the variability of all other genes [15].
Hypothetically, this differential gene should be the most unstable gene in the dataset. In both our species and all treatments (except for the $\mathrm{pH}$ treatment) at least one of the selected differential genes was indeed the most variable of the set tested. This provides evidence that the applied treatments caused an effect at the transcriptional level, which strengthens the validation of the reference genes that remained stable under the changed regimes. The only exception was observed for the $\mathrm{pH}$ treatment, where the pre-selected differential gene was positioned among the housekeeping genes. Most likely, the treatment may not have been severe enough or it may indicate that some exposure types do not initiate an effect on the transcriptional level.

Normfinder performs relative comparisons between the potential reference genes; hence this method is more sensitive to the presence of differentially expressed genes in the dataset than geNorm. In this study, we set a threshold for the maximal allowable bias at 0.13 times the standard deviation of the treatments' intergroup variation as calculated with Normfinder. After the pre-selection, the reference genes selected by geNorm and Normfinder were remarkably similar. In all treatments, except for the F. candida $\mathrm{pH}$ treatment and the O. cincta starvation treatment, the top three consisted of the same three genes even though the order differed.

QRT-PCR has proven its value in many areas of genetic and genomic research. Knowledge on genetic pathways and molecular responses to external environmental cues and chemical factors now also make a significant contribution to evolutionary ecology and ecotoxicology. Experiments in these scientific disciplines often focus on nonmodel organisms, such as Collembola, and routinely use large sample sizes. Now that high-throughput systems QRT-PCR are becoming available [1], the technique will become even more valuable for molecular ecological research. The reference genes presented in this study can therefore act as a starting point for scientists who use identical collembolan species for ecological, evolutionary and ecotoxicological research. Nonetheless, as previously stated by Stürzenbaum and Kille [33], it should always be kept in mind that techniqually successful QRT-PCR depends not only on the genes of interest alone, and therefore reference genes should be carefully validated prior to experimentation.

\section{Methods}

\section{Collembola cultures}

Folsomia candida was kept in plastic containers with a water-saturated plaster of Paris bottom containing $10 \%$ charcoal at $20^{\circ} \mathrm{C}$ in a $12: 12$ light dark regime. The animals were fed dried baker's yeast (Dr. Oetker) ad libitum. For all experiments animals of at least 20 days old were used. 
Orchesella cincta was held comparably, but fed algae (Desmococcus sp) growing on twigs of pine trees. For all the experiments animals of 4-5 weeks old were used, with a maximum age difference of seven days.

\section{Folsomia candida treatments}

$\mathrm{pH} \&$ temperature treatment

Animals of 20 days old were exposed in $100 \mathrm{ml}$ jars with 30 grams of OECD artificial soil. OECD soil $\mathrm{pH}$ was adjusted with $\mathrm{CaCO}_{3}$ (J.T. Baker) to four different values (3.5, 4.5, $5.5 \& 6.5$ ) according to OECD guideline 207 [34]. Pools of thirty animals per jar were exposed to the different $\mathrm{pH}$ values for three days at $75 \%$ humidity and $20^{\circ} \mathrm{C}$. For the temperature treatment OECD soil at a pH of 5.5 was used. Pools of thirty animals per jar were exposed to $0,10,20$ and $30^{\circ} \mathrm{C}$ for 3 days. For each condition two biological replicates were used (separately) for RNA extraction.

\section{Desiccation treatment}

Drought exposure was performed as described by Bayley and Holmstrup [35]. Per replicate, a pool of twenty-five to thirty animals was exposed in plastic containers to a relative air humidity controlled at $98.2 \%$ by placing a $\mathrm{NaCl}$ solution of $31.6 \mathrm{~g} \mathrm{~L}^{-1}$ inside the closed container. Animals were sacrificed after 8, 27, 53 and 174 hours of exposure for RNA isolation. For each condition two biological replicates were used (separately) for RNA extraction.

\section{Cadmium and phenanthrene treatment}

For the cadmium and phenanthrene treatments animals were exposed in $100 \mathrm{ml}$ jars on a compressed layer of 10 g wet weight of LUFA 2.2 soils (for details see [36]). Procedures of the standard ISO protocol 11267 [18] were followed to spike the soils to nominal concentrations equivalent to the LC50 28 days for cadmium $(6.86 \mathrm{mmol}$ $\mathrm{kg}^{-1}$ dry soil [37]) and phenanthrene (422 $\mu \mathrm{mol} \mathrm{kg}{ }^{-1}$ dry soil [36]). For the cadmium spiking a solution of hydrated $\mathrm{CdCl}_{2}$ (purity 99\%; J.T. Baker, The Netherlands) was used, while phenanthrene (purity 96\%; Sigma-Aldrich Chemie, Germany) was dissolved in acetone (Riedel-de Haën, Seelze, Germany), followed by an overnight evaporation time for the acetone. Both soils did not undergo a period of aging. Pools of 15 animals per jar were exposed for a period of $48 \mathrm{hr}$ (cadmium) or $96 \mathrm{hr}$ (phenanthrene) to spiked and clean control soils. For each condition four biological replicates were used (separately) for RNA extraction.

\section{O. cincta treatments Cadmium treatment}

Cadmium exposure was performed as described in Roelofs et al. [25]. Animals were exposed individually to a nominal concentration of $1 \mu$ mole cadmium per gram dry weight food (algal paste). The exposure was started immediately after moulting to exclude hormonal effects on gene expression and lasted for three days. Five individuals were pooled per replicate; a control was used with the same set-up but fed clean algae. For each condition three biological replicates were used (separately) for RNA extraction.

\section{Temperature exposure}

Springtails were exposed in glass vials containing slightly moistened foam at the bottom and moistened foam stoppers. Five individuals per vial were exposed to three temperature treatments: cold $\left(10^{\circ} \mathrm{C}\right)$, control $\left(20^{\circ} \mathrm{C}\right)$ and heat $\left(35^{\circ} \mathrm{C}\right)$. Temperature treatments consisted of four hours at $10^{\circ} \mathrm{C}$ respectively $20^{\circ} \mathrm{C}$ in a climate room, or one hour placement in a water bath of $35^{\circ} \mathrm{C}$ with a one hour recovery period at $20^{\circ} \mathrm{C}$. For each condition three biological replicates of five pooled animals were used (separately) for RNA extraction.

\section{Desiccation treatment}

The desiccation treatment followed the protocol described by Bahrndorff et al. [38]. Springtails were exposed to $97.2 \%$ relative humidity in a tightly sealed container containing a $\mathrm{NaCl}$ solution of $50.66 \mathrm{~g} \mathrm{~L}^{-1}$ at $20^{\circ} \mathrm{C}$ for five days. The control treatment followed the same protocol, but instead of the $\mathrm{NaCl}$ solution demineralized water was used. We used five individuals per vial and three vials per treatment. Animals from each vial were pooled for RNA isolation.

\section{Starvation treatment}

We used five individuals per vial and three vials for the starvation treatment and its control. Springtails were transferred to glass vials containing slightly moistened foam at the bottom and moistened foam stoppers. In the control treatment food was made available by adding a piece of bark overgrown with green algae to the animals, while the animals in the starvation treatment did not have access to food. The experimental vials were kept at $20^{\circ} \mathrm{C}$ in a 12:12 light dark regime for 8 days. Animals from each vial were pooled for RNA isolation.

\section{RNA isolation and reverse transcription}

After exposure animals were snap-frozen in liquid nitrogen and total RNA was isolated with the SV Total RNA isolation system (Promega) according to manufacturer's instructions. Genomic DNA was removed via a DNAse treatment supplied with the kit. RNA integrity was confirmed on a $1 \%$ agarose gel and RNA quantities were assessed with a nanodrop ND-1000 spectrophotometer (Nanodrop Technologies) and ranged between 30 and $100 \mathrm{ng} \mu \mathrm{L}^{-1}$ of total RNA. As indicated by $260 / 280$ and $260 / 230 \mathrm{~nm}$ ratios, all samples used in this study were assumed free from protein contamination and (organic) salts. Absence of amplicons after PCR with Taq-polymerase (MRC Holland, The Netherlands) and $1 \mu \mathrm{L}$ RNA solu- 
tion confirmed that no trace DNA contamination was present in the samples used in the further analyses.

Synthesis of cDNA was performed using the reverse-transcriptase system of Promega with the M-MLV reverse transcriptase enzyme and an oligo-dT primer $(F$. candida samples) or random hexamer primers (O. cincta). Random hexamer primers were used in the case of $O$. cincta because $28 \mathrm{~S}$ ribosomal RNA was used as one of the potential reference genes. In the case of the $O$. cincta samples, reverse transcription input amounts were equalized by diluting the total RNA concentrations to $0.5 \mu \mathrm{g} \mu \mathrm{L}^{-1}$, and samples were reverse transcribed together in a single run. cDNA samples were diluted 4 times before QPCR was carried out. All treatment conditions were reverse transcribed in triplicate, except for the $\mathrm{pH}$ treated samples which were performed in duplicate.

\section{QPCR}

Besides reference genes, one or two differentially expressed genes were included in order to observe transcriptional effects of the treatment. These differentials were previously assessed for their response to the majority of the treatments $([25,39,40]$, TE de Boer, MJTN Timmermans, unpubl. data). For the desiccation and starvation treatments in O. cincta, lack of prior knowledge of characteristic responsive genes made us look to a fixed set of two differentials for all four treatments. QPCR assays for seven candidate reference genes (Table 1) and two genes differential for a range of stressful conditions, HSP70 and MT, $[41,42]$ were developed. For F. candida, eight candidate reference genes were analyzed (Table 1 ) together with one differential gene for each treatment. Primers were based on sequences present in the Collembola EST database Collembase http://www.collembase.org and generated with Primer Express 1.5 (Applied Biosystems) with the following settings: Melting temperatures were kept between $59^{\circ} \mathrm{C}$ and $60^{\circ} \mathrm{C}$ and the amplified fragment length was kept between 90 and 120 base pairs with an optimum amplicon melting temperature of $80^{\circ} \mathrm{C}$. For primer sequences, GC content and melting temperatures (see Additional file 4). Details on the positions of the QPCR amplicons in the full coding sequences are given in (Additional file 5).

Reaction efficiency of each of the QPCR assays was determined by means of a standard curve consisting of 5 samples each four fold diluted, from an initial cDNA pool. Each reaction was carried out in a total volume of $20 \mu \mathrm{L}$, using $2 \mu \mathrm{L}$ cDNA template, $10 \mu \mathrm{L}$ SYBR Green I master mix (Applied Biosystems) and 20 pmole of each gene specific primer (supplied by Isogen). QPCR Cycling was performed on an DNA engine Opticon1 (Biorad), with three technical replicates per sample. Cycling conditions were kept constant for all assays. For details on PCR mix and program see Roelofs et al. [25]). Specificity of the PCR products was confirmed after each amplification by analysis of the melting curve; $60-90^{\circ} \mathrm{C}$ with a heating rate of $0.1^{\circ} \mathrm{C}$ per second and one fluorescence measurement per second. Each run included a non-template control for each assay.

For two of the O. cincta assays (GAPDH and SDHA) no sequence information was available. Therefore degenerate primers were developed based on sequences from multiple organisms that were taken from Genbank. Generated PCR templates were subsequently cloned, sequenced and used as a template for QPCR primers as described above. Proper QPCR data were not retrieved from one F. candida $\mathrm{pH}$ treatment replicate ( $\mathrm{pH}$ 3.5). Therefore this sample was discarded from further analysis.

\section{Data analysis}

Ct values were calculated with the Opticon Monitor 3 software (Biorad), using a manually set cycle threshold. At a level of 0.01 raw fluorescent units which in all assayed plates fell within the exponential phases of the QPCR reactions. Averages of the three technical replicates were used in case of a standard deviation $\leq 0.5$. When standard deviation exceeded this number, fluorescence curves were evaluated. The analysis was always based on at least two replicates.

Ranking of reference genes was determined using geNorm and Normfinder applications, as implemented in the Genex Light software package [43]. Optimum numbers of reference genes are based on a $\mathrm{Vn} / \mathrm{Vn}+1$ value of $>0.15$ for geNorm [15] and the minimum of accumulated standard deviations for Normfinder [17]. The original geNorm VBA applet for Excel was used for automated calculation of $\mathrm{Vn} /$ $\mathrm{Vn}+1$.

Relative gene expressions of all differential genes were calculated with the Pfaffl method [10] and normalized with both of the optimum sets of reference genes proposed by geNorm and Normfinder. Significance levels were tested by Student's t-test, for both algorithms. To be conservative we report only the larger P-value in the results. The temperature exposures of $F$. candida (Figure 2) were normalized as described in the results section, and tested for their significance by one-way ANOVA analysis with a Bonferroni corrected post-hoc test between the different temperatures for each normalization method.

\section{Bias threshold definition}

In Normfinder the total stability ('variability') of a gene is defined by the magnitude of the intragroup variation relative to the intergroup variation [16]. Differential genes, which are responding to one or more treatments, will greatly increase the intergroup variation and hence have a disproportionally large effect on the calculated variability and the ranking order of the other candidate genes. To 
avoid such biases, differential genes should be excluded from the NormFinder analysis using a pre-selection procedure. The pre-selection procedure consisted of an initial NormFinder analysis with all genes, from which we calculated a bias threshold for the amount of total absolute bias a gene was allowed to have, compared to the total mean absolute bias of the group. Assuming a normal distribution of biases and genes, we considered the 10\% most stable genes to be suitable as potential reference genes, which sets the bias threshold between $-0.13 * \mathrm{SD}$ and $0.13 * S D$ of the normal distribution [44]. In the final NormFinder analysis only those genes that met the criterion of being among the $10 \%$ most stable genes were included. Ranking of the remaining genes was subsequently done by determining the standard deviation in a Normfinder analysis with the software settings set to not taking groups into account (M. Kubista, pers. comm.).

\section{Authors' contributions}

MEB, TEB, DR, JE and NMvS conceived the study, set up its design and drafted the manuscript. MEB and TEB conducted the F. candida experiments and the QRT-PCR work. JE and DR performed the O. cincta treatments and RNA extractions. JM sequenced and designed the QPCR assays for the unknown genes. MJTNT partially generated material for the F. candida desiccation analysis and helped with QPCR assay design. BN helped conducting some of the treatments. All authors helped shaping and approved the final manuscript.

\section{Additional material}

\section{Additional file 1}

Expression levels of reference genes and differentially expressed genes in Folsomia candida and Orchesella cincta.

Click here for file

[http://www.biomedcentral.com/content/supplementary/1471-

2199-10-54-S1.doc]

\section{Additional file 2}

GeNorm analyses of species overlapping treatments and genes.

Click here for file

[http://www.biomedcentral.com/content/supplementary/1471-

2199-10-54-S2.doc]

\section{Additional file 3}

Normfinder analyses of Orchesella cincta genes over all treatments. Click here for file

[http://www.biomedcentral.com/content/supplementary/14712199-10-54-S3.doc]

\section{Additional file 4}

Primer sequences and parameters for the QPCR assays used in this study.

Click here for file

[http://www.biomedcentral.com/content/supplementary/1471-

2199-10-54-S4.doc]

\section{Additional file 5}

Locations of QRT-PCR amplicons in coding sequence.

Click here for file

[http://www.biomedcentral.com/content/supplementary/14712199-10-54-S5.doc]

\section{Acknowledgements}

The authors of this paper would like to thank Mikael Kubista for help with the Genex software and the data analysis and Martin Holmstrup for providing the samples for the $F$. candida desiccation treatment. This work was supported by grants from the Netherlands Genomics Initiative (BSIK program "Ecogenomics: Assessing the Living Soil"). JE is supported by the Netherlands Organization for Scientific Research, VIDI-grant no. 864.03.003.

\section{References}

I. Morrison T, Hurley J, Garcia J, Yoder K, Katz A, Roberts D, Cho J, Kanigan T, llyin SE, Horowitz D, Dixon JM, Brenan C: Nanoliter high throughput quantitative PCR. Nucleic Acids Res 2006, 34(18):

2. Snell TW, Brogdon SE, Morgan MB: Gene Expression Profiling in Ecotoxicology. Ecotoxicology 2003, I 2(6):475-483.

3. Ellers J, Mariën J, Driessen G, Van Straalen NM: Temperatureinduced gene expression associated with different thermal reaction norms for growth rate. J Exp Zool 2008, 3 I0B(2):137-I 47.

4. Muller WEG, Grebenjuk VA, Thakur NL, Thakur AN, Batel R, Krasko $A$, Muller IM, Breter $H$ J: Oxygen-controlled bacterial growth in the sponge Suberites domuncula: toward a molecular understanding of the symbiotic relationships between sponge and bacteria. Appl Environ Microbiol 2004, 70(4):2332-234I.

5. Scharf ME, Wu-Scharf D, Pittendrigh BR, Bennett GW: Caste- and development-associated gene expression in a lower termite. Genome Biol 2003, 4( I 0): II.

6. Zientz E, Beyaert N, Gross R, Feldhaar H: Relevance of the endosymbiosis of Blochmannia floridanus and carpenter ants at different stages of the life cycle of the host. Appl Environ Microbiol 2006, 72(9):6027-6033.

7. Roelofs D, Mariën J, Van Straalen NM: Differential gene expression profiles associated with heavy metal tolerance in the soil insect Orchesella cincta. Insect Biochem Mol Biol 2007, 37(4):287-295

8. Bustin SA: Quantification of mRNA using real-time reverse transcription PCR (RT-PCR): trends and problems. J Mol Endocrinol 2002, 29(I):23-39.

9. Applied_Biosystems: Comparative CT Method (Separate Tubes). User Bulletin 2: Rev. B ABI Prism 7700 Sequence Detection System 200I, 2:II-I5.

10. Pfaffl MW: A new mathematical model for relative quantification in real-time RT-PCR. Nucleic Acids Res 200I, 29(9):2002-2007.

II. Huggett J, Dheda K, Bustin S, Zumla A: Real-time RT-PCR normalisation; strategies and considerations. Genes Immun 2005, 6(4):279-284.

12. Heckmann L-H, Connon R, Hutchinson T, Maund S, Sibly R, Callaghan A: Expression of target and reference genes in Daphnia magna exposed to ibuprofen. BMC Genomics 2006, 7(I): 175.

13. Bas A, Forsberg G, Hammarstrom S, Hammarstrom ML: Utility of the Housekeeping Genes I8S rRNA, beta-Actin and Glyceraldehyde-3-Phosphate-Dehydrogenase for Normalization in Real-Time Quantitative Reverse Transcriptase-Polymerase Chain Reaction Analysis of Gene Expression in Human T Lymphocytes. Scand J Immunol 2004, 59(6):566-573.

14. Zhong H, Simons JW: Direct Comparison of GAPDH, betaActin, Cyclophilin, and 28S rRNA as Internal Standards for Quantifying RNA Levels under Hypoxia. Biochem Biophys Res Commun 1999, 259(3):523-526.

15. Vandesompele J, De Preter K, Pattyn F, Poppe B, Van Roy N, De Paepe A, Speleman F: Accurate normalization of real-time quantitative RT-PCR data by geometric averaging of multi- 
ple internal control genes. Genome Biol 2002, 3(7):research0034.003I-research0034.00II.

16. Andersen CL, Jensen JL, Orntoft TF: Normalization of Real-Time Quantitative Reverse Transcription-PCR Data: A ModelBased Variance Estimation Approach to Identify Genes Suited for Normalization, Applied to Bladder and Colon Cancer Data Sets. Cancer Res 2004, 64(I 5):5245-5250.

17. Bergkvist A, Forootan A, Zoric N, Strombom L, Sjoback R, Kubista M: Choosing a Normalization Strategy for RT-PCR. Genet Eng Biotechn N 2008, 28(13): I.

18. ISO: ISO, Soil Quality. Inhibition of Reproduction of Collembola (Folsomia candida). ISO Guideline II267. International Standardization Organization. Switzerland; 1999:16.

19. Fountain MT, Hopkin SP: Folsomia candida (Collembola): A "standard" soil arthropod. Annu Rev Entomol 2005, 50:20I-222.

20. Timmermans MJTN, De Boer ME, Nota B, De Boer TE, Mariën J, Klein-Lankhorst RM, Van Straalen NM, Roelofs D: Collembase: a repository for springtail genomics and soil quality assessment. BMC Genomics 2007, 8(34I): I0.

21. Timmermans MJTN, Ellers J, Van Straalen NM: Allelic diversity of metallothionein in Orchesella cincta (L.): traces of natural selection by environmental pollution. Heredity 2007, 98(5):3|I-3|9.

22. Nota B, Timmermans MJTN, Franken O, Montagne-Wajer K, Mariën J, De Boer ME, De Boer TE, Ylstra B, Van Straalen NM, Roelofs D: Gene Expression Analysis of Collembola in Cadmium Containing Soil. Environ Sci Technol 2008, 42(2I):8I 52-8I57.

23. Bahrndorff S, Holmstrup M, Petersen H, Loeschcke V: Geographic variation for climatic stress resistance traits in the springtail Orchesella cincta. J Insect Physiol 2006, 52(9):95 I-959.

24. Liefting M, Ellers ]: Habitat-specific differences in thermal plasticity in natural populations of a soil arthropod. Biol J Linn Soc 2008, 94(2):265-27I.

25. Roelofs D, Overhein L, De Boer ME, Janssens TKS, Van Straalen NM: Additive genetic variation of transcriptional regulation: metallothionein expression in the soil insect Orchesella cincta. Heredity 2006, 96(I):85-92.

26. Spinsanti G, Panti C, Lazzeri E, Marsili L, Casini S, Frati F, Fossi C Selection of reference genes for quantitative RT-PCR studies in striped dolphin (Stenella coeruleoalba) skin biopsies. BMC Mol Biol 2006, 7(I):32.

27. Sinclair BJ, Gibbs AG, Roberts SP: Gene transcription during exposure to, and recovery from, cold and desiccation stress in Drosophila melanogaster. Insect Mol Biol 2007, 16(4):435-443.

28. Bustin SA, Benes V, Nolan T, Pfaffl MW: Quantitative real-time RT-PCR - a perspective. J Mol Endocrinol 2005, 34(3):597-60I.

29. Stahlberg A, Kubista M, Pfaffl M: Comparison of Reverse Transcriptases in Gene Expression Analysis. Clin Chem 2004, 50(9): $1678-1680$.

30. D'Haese CA: Were the first springtails semi-aquatic? A phylogenetic approach by means of 28S rDNA and optimization alignment. P Roy Soc Lond B-Bio 2002, 269( I 496): I I43-I I II.

31. Infante C, Matsuoka MP, Asensio E, Canavate JP, Reith M, Manchado $M$ : Selection of housekeeping genes for gene expression studies in larvae from flatfish using real-time PCR. BMC Mol Biol 2008, 9(28): 12.

32. Scharlaken B, de Graaf DC, Goossens K, Brunain M, Peelman LJ Jacobs FJ: Reference gene selection for insect expression studies using quantitative real-time PCR: The head of the honeybee, Apis mellifera, after a bacterial challenge. J Insect Sci 2008, 8(33): 10.

33. Stürzenbaum SR, Kille P: Control genes in quantitative molecular biological techniques: the variability of invariance. Comp Biochem Physiol B: Biochem Mol Biol 200I, I30(3):28I-289.

34. Organisation for Economic Co-operation and Development: Test no 207: Earthworm, acute toxicity tests. In OECD Guidelines for the testing of chemicals OECD: Paris, France; 1984.

35. Bayley M, Holmstrup M: Water vapor absorption in arthropods by accumulation of myoinositol and glucose. Science 1999 , 285(5435): $|909-19| \mid$.

36. Dröge STJ, Paumen ML, Bleeker EAJ, Kraak MHS, Van Gestel CAM: Chronic toxicity of polycyclic aromatic compounds to the springtail Folsomia candida and the enchytraeid Enchytraeus crypticus. Environ Toxicol Chem 2006, 25(9):2423-2431.

37. Van Gestel CAM, Koolhaas JE: Water-extractability, free ion activity, and $\mathrm{pH}$ explain cadmium sorption and toxicity to
Folsomia candida (Collembola) in seven soil-pH combinations. Environ Toxicol Chem 2004, 23(8): | 822-। 833 .

38. Bahrndorff S, Petersen SO, Loeschcke V, Overgaard J, Holmstrup M: Differences in cold and drought tolerance of high arctic and sub-arctic populations of Megaphorura arctica Tullberg 1876 (Onychiuridae: Collembola). Cryobiology 2007, 55(3):3 I5-323.

39. De Boer ME, De Boer TE, Nota B, Timmermans MJTN, Mariën J, Roelofs D, Van Straalen NM: Application of real-time RT-QPCR to develop new biomarkers for soil quality assessment [abstract]. Comp Biochem Physiol A Mol Integr Physiol 2008, I 5 I (I):S2I-S2I.

40. Bahrndorff S, Loeschcke V, Marien J, Ellers J: Dynamics of heatinduced thermal stress resistance and hsp70 expression in the springtail, Orchesella cincta. Funct Ecol 2009, 23(2):233-239.

4I. Sørensen JG, Kristensen TN, Loeschcke V: The evolutionary and ecological role of heat shock proteins. Ecol Lett 2003, 6(I I): 1025-1037

42. Coyle P, Philcox JC, Carey LC, Rofe AM: Metallothionein: The multipurpose protein. Cell Mol Life Sci 2002, 59(4):627-647.

43. MultiD Analyses $A B$ : GenEx Light Software, version 4.3.5. MultiD Analyses $A B$ Year of release 2008 [http://www.multid.se]

44. Online Statistics: An Interactive Multimedia Course of Study [http://www.onlinestatbook.com]
Publish with Biomed Central and every scientist can read your work free of charge

"BioMed Central will be the most significant development for disseminating the results of biomedical research in our lifetime. "

Sir Paul Nurse, Cancer Research UK

Your research papers will be:

- available free of charge to the entire biomedical community

- peer reviewed and published immediately upon acceptance

- cited in PubMed and archived on PubMed Central

- yours - you keep the copyright

Submit your manuscript here:

http://www.biomedcentral.com/info/publishing_adv.asp
BiolMedcentral 